Article

\title{
Chitosan/Graphene Oxide Nanocomposite Membranes as Adsorbents with Applications in Water Purification
}

\author{
Alexa-Maria Croitoru ${ }^{1,2}$, Anton Ficai $^{1,2, * \mathbb{C}}$, Denisa Ficai ${ }^{2}{ }^{\mathbb{D}}$, Roxana Trusca ${ }^{2}$, \\ Georgiana Dolete 2, Ecaterina Andronescu 1,2 and Stefan Claudiu Turculet ${ }^{3,4}$ \\ 1 Academy of Romanian Scientists, Spl. Independenței 54, 50085 Bucharest, Romania; \\ croitoru.alexa@yahoo.com (A.-M.C.); ecaterina.andronescu@upb.ro (E.A.) \\ 2 Faculty of Applied Chemistry and Materials Science, University Politehnica of Bucharest, Gh. Polizu St 1-7, \\ 011061 Bucharest, Romania; denisaficai@yahoo.ro (D.F.); truscaroxana@yahoo.com (R.T.); \\ dolete.georgiana@gmail.com (G.D.) \\ 3 Faculty of Medicine, Carol Davila University of Medicine and Pharmacy, Eroii Sanitari St 8, \\ 050474 Bucharest, Romania; turculet.claudiu@yahoo.com \\ 4 Emergency Hospital Floreasca Bucharest, Calea Floreasca St 8, 014461 Bucharest, Romania \\ * Correspondence: anton.ficai@upb.ro
}

Received: 12 March 2020; Accepted: 31 March 2020; Published: 4 April 2020

check for updates

\begin{abstract}
The scope of this article is to develop composite membranes using chitosan (CS) and graphene oxide (GO) as adsorbents for the removal of inorganic pollutants such as heavy metal ions, particularly $\mathrm{Pb}^{2+}$, from aqueous solutions. GO was obtained by modified Hummers method and blended with CS solution. The introduction of ethylenediaminetetraacetic acid (EDTA) compound to CS/GO suspension lead to an increased adsorption capacity of CS/GO for the elimination of heavy metals by forming stable chelates with them. The synthesized membranes were examined by Fourier transform infrared spectroscopy (FTIR) and scanning electron microscopy (SEM), and the adsorption behaviour of $\mathrm{Pb}^{2+}$ from aqueous solutions using CS/EDTA/GO membranes was evaluated using inductively coupled plasma mass spectrometry (ICP-MS). The adsorption performance of $\mathrm{Pb}^{2+}$ ions was studied by monitoring the concentration of $\mathrm{Pb}^{2+}$ against the adsorption period at an initial content of the adsorbent. The maximum adsorption efficiency of $\mathrm{Pb}^{2+}$ metal ions reached $767 \mathrm{mg} \cdot \mathrm{g}^{-1}$ for CS/EDTA/GO $0.1 \%, 889 \mathrm{mg} \cdot \mathrm{g}^{-1}$ for CS/EDTA/GO $0.3 \%, 970 \mathrm{mg} \cdot \mathrm{g}^{-1}$ for CS/EDTA, $853 \mathrm{mg} \cdot \mathrm{g}^{-1}$ for $\mathrm{CS}$ and $1526 \mathrm{mg} \cdot \mathrm{g}^{-1}$ for GO. These findings show promising potential for CS/EDTA/GO membranes as effective adsorbent materials for the removal of heavy metal ions in water.
\end{abstract}

Keywords: chitosan; graphene oxide; EDTA; lead; nanoadsorbent

\section{Introduction}

In the last several years, the presence of toxic pollutants (antibiotics, pesticides, heavy metals, etc.) in wastewater has become a concerning problem affecting the ecological environment and human health in the long term. The enhancement of heavy metal ion concentrations in potable water, surface water and ground water affect human and animal life [1]. Thus, the elimination of contaminants like inorganic metal ions from wastewater is very important, as they are encountered infertilizer, the production of different plastics, mining, metallurgy, electroplating, chemical manufacturing and so forth [2-5]. Heavy metals can have a dangerous impact on human health, even at low concentrations. Compared to organic contaminants, heavy metals $\left(\mathrm{Cr}^{6+}, \mathrm{Pb}^{2+}, \mathrm{Hg}^{2+}\right.$, etc. $)$ are imperishable and tend to accumulate in living organisms, causing toxic effects such as high blood pressure, fatigue, irritability, increased allergic reactions and autoimmune diseases [6]. At present, numerous techniques are used for the removal of 
metal ions, including reduction, co-precipitation, UV photolysis/photocatalysis, membrane filtration, ion exchange and adsorption. Of all these methods, adsorption is the most significant process because of its advantages, such as the relatively low cost and convenience of use [7,8]. Therefore, new strategies have been developed using nanoadsorbents based on nanotechnologies $[9,10]$. Numerous porous materials have been studied and developed for use as adsorbents (activated carbon, graphene oxide (GO), zeolite, $\mathrm{CuO}, \mathrm{ZnO}$, silica and polymeric adsorbent) for the removal of pollutants [11]. Lately, carbon-based materials (nanotubes, graphene oxides, etc.) have been shown to be promising materials for different applications, such as surface-enhanced Raman scattering and metamaterials [12], solar cells [13], and batteries and other energy storage devices [14,15], but they also have been studied as adsorbents in environmental applications for water purification [16]. Among carbon materials, graphene oxide presents a high adsorption capacity because of its particular properties: high specific surface area, rich oxygen functional sites with both hydrophilic and hydrophobic groups and good thermal and chemical stability. Thus, graphene oxide can be used in the decontamination of wastewater due to its adsorption properties, having the ability to remove one or more toxic compounds [17-19].

Chitosan (CS) has been considered a potential adsorbent material for the elimination of toxic pollutants due to its amino and hydroxyl groups [20], physico-chemical properties such as chemical stability, and high reactivity and selectivity toward pollutants and outstanding chelation behavior [21]. CS is non-toxic and biodegradable, and its production cost is low [11].

Ethylenediaminetetraacetic acid (EDTA) has been studied in the elimination of toxic metals because it forms stable chelates with metal ions [8].

Based on the literature data, scientists studied the removal of organic and inorganic contaminants using new materials based on GO [22,23]. In the past few years, GO and its derivatives have been studied for their adsorption properties for organic and inorganic contaminants in aqueous solutions [24-26]. Harijan et al. [27] investigated the effective removal of $\mathrm{Cr}^{6+}$ from water using a GO material functionalized with polyaniline (PANI-GO). The maximum adsorption capacity for PANI-GO was up to $192 \mathrm{mg} \cdot \mathrm{g}^{-1}$ in $20 \mathrm{~min}$ where $\mathrm{pH}$ was 6.5 and temperature was $30^{\circ} \mathrm{C}$. With the decrease of $\mathrm{pH}$ and enhancement of the initial concentration of $\mathrm{Cr}^{6+}$, the adsorption capacity for $\mathrm{Cr}^{6+}$ increased. EDTA functionalized with GO was used as adsorbent material for the elimination of $\mathrm{Pb}^{2+}$. The best adsorption efficiency reached $479 \pm 46 \mathrm{mg} \cdot \mathrm{g}^{-1}$ in $20 \mathrm{~min}$ at a $\mathrm{pH}$ value of 6.8 [8].

These findings show that GO and its derivatives can be efficient adsorbents for the environment, especially concerning water treatment. This study was realized to examine the adsorption process and the potential applications of CS/EDTA/GO membranes in the elimination of $\mathrm{Pb}^{2+}$ ions from wastewater. The adsorption properties of the obtained materials were investigated by monitoring the concentration of $\mathrm{Pb}^{2+}$ against the adsorption period at an initial content of the adsorbent.

\section{Materials and Methods}

Low molecular weight chitosan (MW of $190 \mathrm{kDa}$ and deacetylation degree of 75-85\%), phosphorus pentoxide, potassium peroxydisulfate and lead(II) chloride $99.999 \%$ were acquired from Sigma-Aldrich (Steinheim, Germany). Graphite (natural powder), potassium permanganate (Lach-Ner, Neratovice, Czech Republic), glacial acetic acid (Chimreactiv, Bucharest, Romania), sulphuric acid $95 \%-97 \%$ and ethylenediaminetetraacetic acid (EDTA) were from Merck (Darmstadt, Germany). Hydrogen peroxide $35 \%$ and hydrochloric acid were from Silal Trading (Bucharest, Romania).

\subsection{Fabrication of $G O$}

To synthesize GO, a modified Hummers method was used; the steps are presented in Scheme 1 [28, 29]. Graphite powder ( $20 \mathrm{~g})$ was blended with a mixed solution containing $60 \mathrm{~mL} \mathrm{H}_{2} \mathrm{SO}_{4}, 10 \mathrm{~g} \mathrm{P}_{2} \mathrm{O}_{5}$ and $10 \mathrm{~g} \mathrm{~K}_{2} \mathrm{~S}_{2} \mathrm{O}_{8}$ heated in advance to $80^{\circ} \mathrm{C}$. The solution was filtered after cooling and rewashed until the filtrate had no residual acid. The resulting material was dried at $80^{\circ} \mathrm{C}$ for $24 \mathrm{~h}$. The dried product $(20 \mathrm{~g})$ was added slowly to $460 \mathrm{~mL}$ of concentrated $\mathrm{H}_{2} \mathrm{SO}_{4}$ solution with a temperature below $5{ }^{\circ} \mathrm{C}$. Sixty grams of $\mathrm{KMnO}_{4}$ was added slowly, and the suspension was stirred at $35^{\circ} \mathrm{C}$ for $2 \mathrm{~h}$ until it 
became yellowish-brown. The solution was diluted with about $3 \mathrm{~L}$ of deionized water and stirred for $15 \mathrm{~min}$ and finally, to eliminate the excess of $\mathrm{KMnO}_{4}, 50 \mathrm{~mL}$ of $30 \% \mathrm{H}_{2} \mathrm{O}_{2}$ was added. The solution mixture was rewashed with $5 \% \mathrm{HCl}$ and deionized water until the $\mathrm{pH}$ became neutral. The resulting product was dried in an oven for $24 \mathrm{~h}$ at $60^{\circ} \mathrm{C}$, and GO was obtained [29].

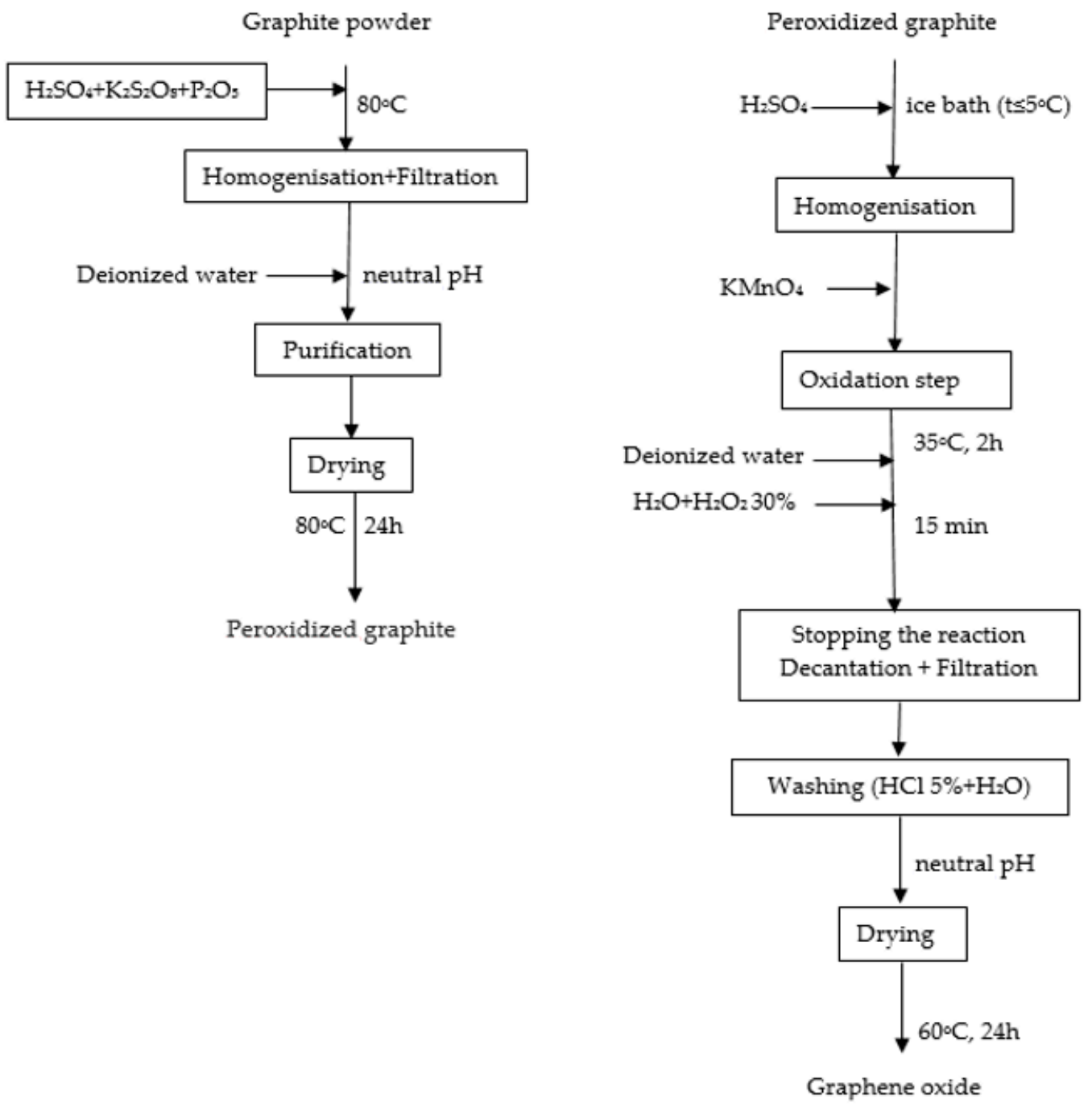

Scheme 1. Synthesis of graphene oxide (GO) [29].

\subsection{Preparation of CS/EDTA Composite Solution}

A solution of chitosan ( $2 \%)$ was prepared in glacial acetic acid $(90 \mathrm{wt} \%)$ and deionized water and mixed for $24 \mathrm{~h}$ at room temperature using a magnetic stirrer. Also, a solution of EDTA was prepared having a final concentration of $2 \%$ relative to chitosan. The two solutions were mixed and kept without stirring for $1 \mathrm{~h}$ at room temperature to allow the release of air bubbles after stirring.

\subsection{Preparation of CS/EDTA/GO Films}

Known amounts of GO (0.01 and $0.03 \mathrm{~g}$ ) were dispersed in $10 \mathrm{~mL}$ CS/EDTA and treated by mild sonication for $15 \mathrm{~min}$ until homogenous suspensions were formed. The obtained suspensions were then stirred for $1 \mathrm{~h}$ at room temperature and cast on two Petri glasses, forming a gel-like sheet with a thickness of approximately $1 \mathrm{~mm}$. The composite membranes were dried in the oven for $24 \mathrm{~h}$ at $40{ }^{\circ} \mathrm{C}$ (Scheme 2). The CS and CS/EDTA films were prepared according to the same method. Figure 1 presents the obtained films. 


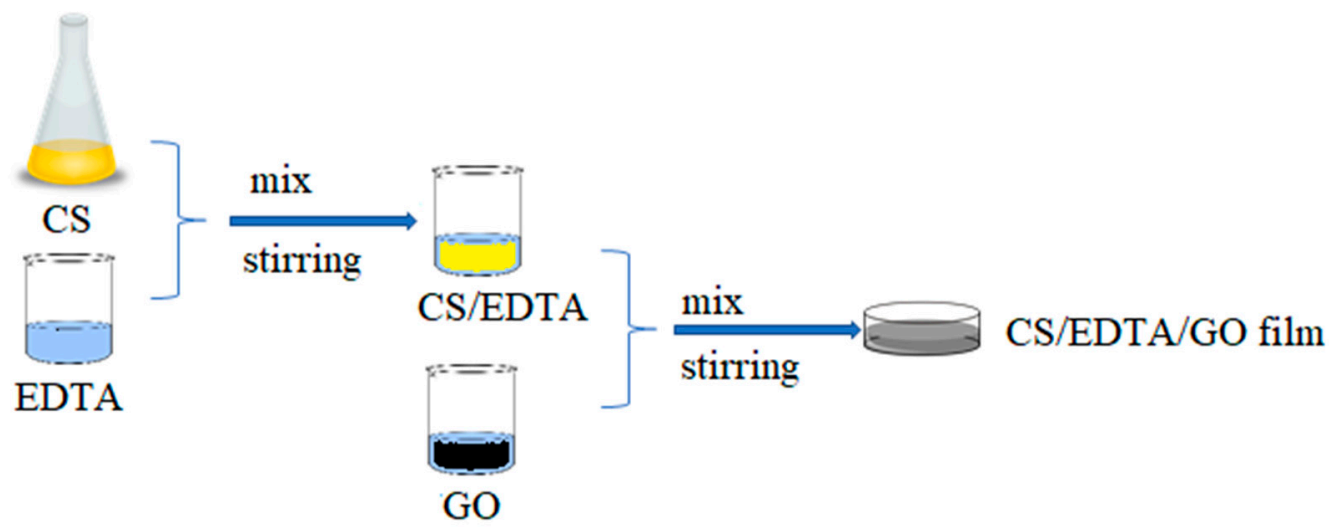

Scheme 2. Schematic illustration of the preparation of chitosan (CS)/ ethylenediaminetetraacetic acid (EDTA)/GO films.

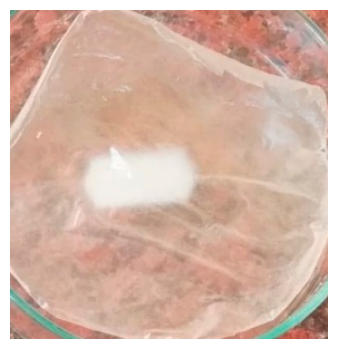

(a)

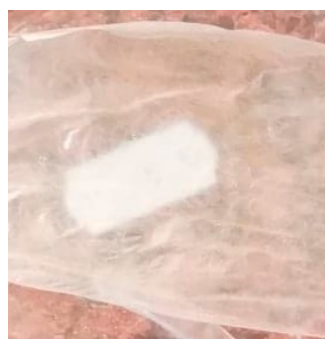

(b)

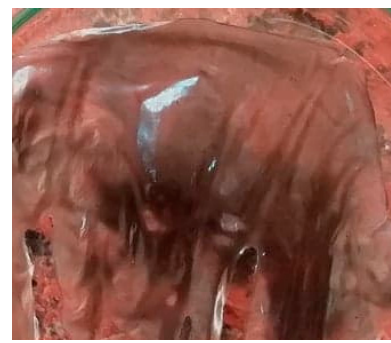

(c)

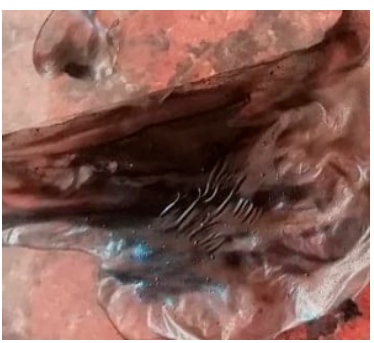

(d)

Figure 1. Digital photos of the samples: (a) chitosan (CS) film, (b) chitosan/ethylenediaminetetraacetic acid (CS/EDTA) film, (c) chitosan/ethylenediaminetetraacetic acid/graphene oxide (CS/EDTA/GO) film $0.1 \%$, and (d) CS/EDTA/GO film $0.3 \%$.

The synthesized membranes were examined by IR spectroscopy using a Nicolet iS50 spectrophotometer (MA, USA) containing a deuterated triglycine sulfate (DTGS) detector that provided high sensitivity information. Measurements of the membranes were recorded from 4000 to $100 \mathrm{~cm}^{-1}$ with a resolution of $4 \mathrm{~cm}^{-1}$. All spectra were registered in Attenuated Total Reflectance (ATR) mode using a diamond crystal.

Morphological data were determined by scanning electron microscopy (SEM). The prepared films were characterized via a Quanta Inspect F50 electron microscope (Eindhoven, Nederlands) equipped with a field emission gun (FEG) having a resolution of $1.2 \mathrm{~nm}$.

\subsection{Adsorption Experiments}

Lead concentration was determined using inductively coupled plasma mass spectrometry equipment (Agilent 8800 ICP-MS Triple Quadrupole, Agilent Technologies) (SC, USA). The measurements were performed for ${ }^{208} \mathrm{~Pb}$ isotope, and the quantification of the results was made by an external calibration method using a multi-element standard solution of $100 \mu \mathrm{g} / \mathrm{mL}$ for which the calibration curve points were prepared. The calibration curve for ${ }^{208} \mathrm{~Pb}$ isotope was linear in the range of $100-1300 \mu \mathrm{g} / \mathrm{L}$ with a correlation coefficient of $R^{2}=0.9985$. The detection limit of the equipment for ${ }^{208} \mathrm{~Pb}$ was $0.01109 \mu \mathrm{g} / \mathrm{L}$.

To determine the adsorption capacity, a solution of $\mathrm{PbCl}_{2}$ was obtained by dissolving $1.5 \mathrm{~g} \mathrm{PbCl}_{2}$ $\left(\mathrm{Pb}^{2+} 1.1 \mathrm{~g} / \mathrm{L}\right)$ in $1000 \mathrm{~mL}$ of deionized water. The adsorption experiments were realized by taking a fixed mass of dry film $(20 \mathrm{mg})$ in $15 \mathrm{~mL}$ of metal solution. All samples were done in triplicate in order to avoid errors and to assess the homogeneity of the samples. As for GO, $20 \mathrm{mg}$ of powder was added to $15 \mathrm{~mL}$ of metal solution. A quantity of $1 \mathrm{~mL}$ of each mixture was collected periodically $(10,20,30,45$ and $60 \mathrm{~min}$ ), and the final solutions were adjusted by serial dilution. Each sample was analyzed using ICP-MS to determine the adsorption capacity of each film. 
The following equation was used to calculate the amount of metal ions adsorbed on membranes [1]:

$$
q=\frac{\left(C_{0}-C_{e}\right) * V}{m}
$$

where $q$ is the adsorption capacity in $\mathrm{mg} \cdot \mathrm{g}^{-1}, C_{0}$ and $C_{e}$ are the initial and equilibrium concentrations of $\mathrm{Pb}^{2+}$ in $\mathrm{mg} / \mathrm{L}, V$ is the volume of the solution in $\mathrm{L}$ and $m$ is the weight of the adsorbent in $\mathrm{g}$.

\section{Results}

This paper presents the characterization of CS, CS/EDTA and CS/EDTA/GO membranes with different amounts of $\mathrm{GO}$ and their application as adsorbents for the elimination of $\mathrm{Pb}^{2+}$ ions from water.

Figure 2 shows FTIR spectra of CS and CS/EDTA films.

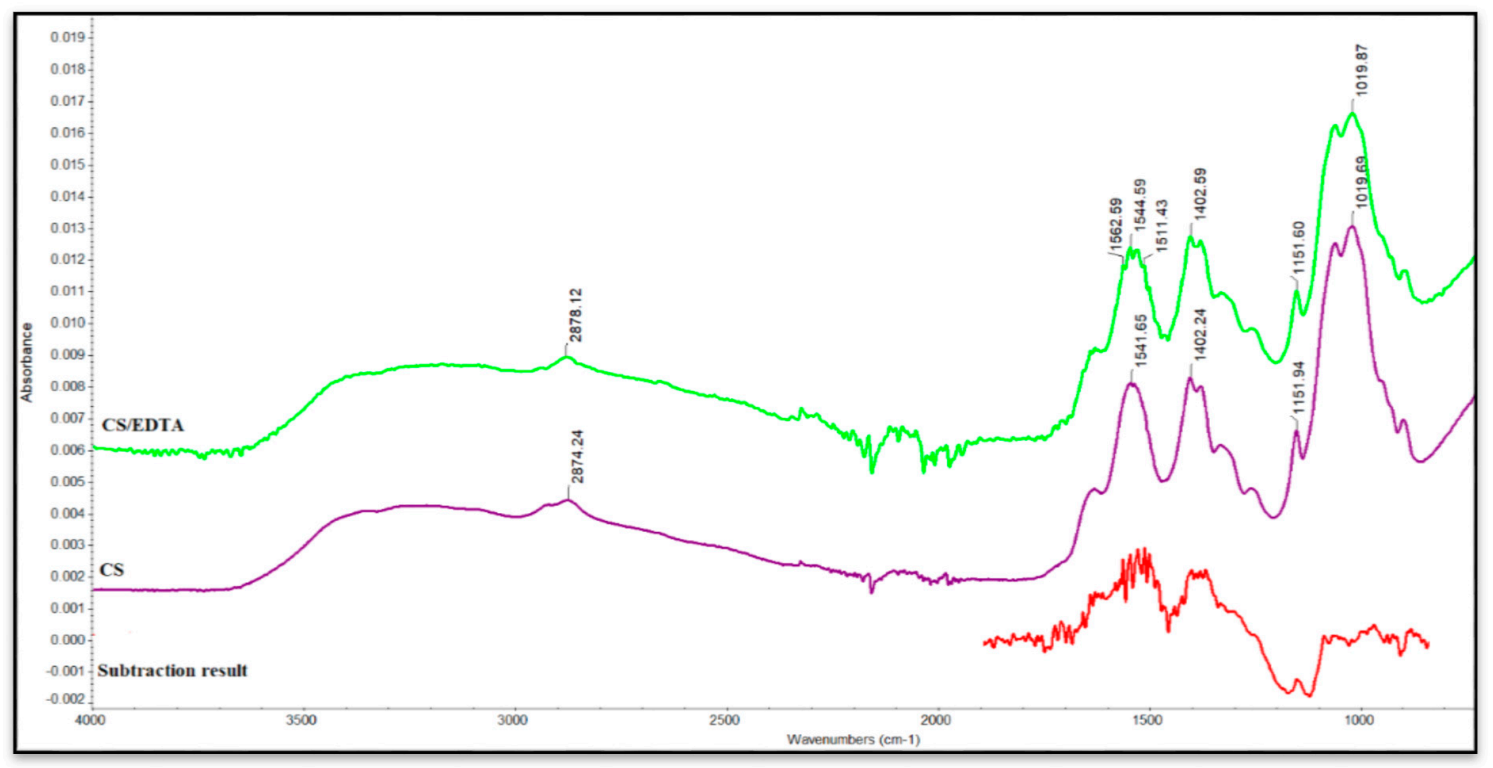

Figure 2. Fourier Transform Infrared Spectroscopy (FTIR) spectra for CS and CS/EDTA films.

Figure 3 presents the FTIR spectra of GO and the as-prepared CS/EDTA/GO membranes at different GO concentrations.

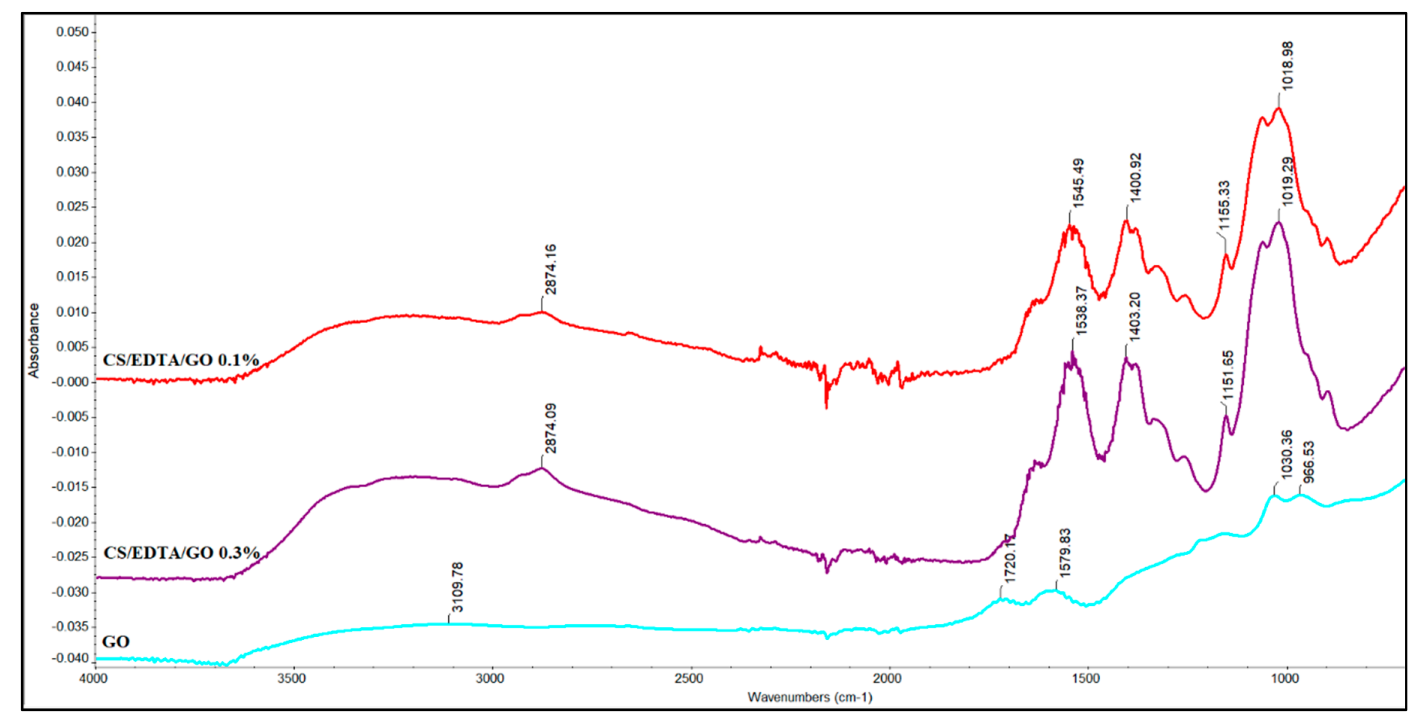

Figure 3. FTIR spectra for GO, CS/EDTA/GO 0.1\% and CS/EDTA/GO 0.3\%. 
Figure 4 presents the morphology of GO at $1000 \times$ and $50 \mathrm{k} \times$ magnification.

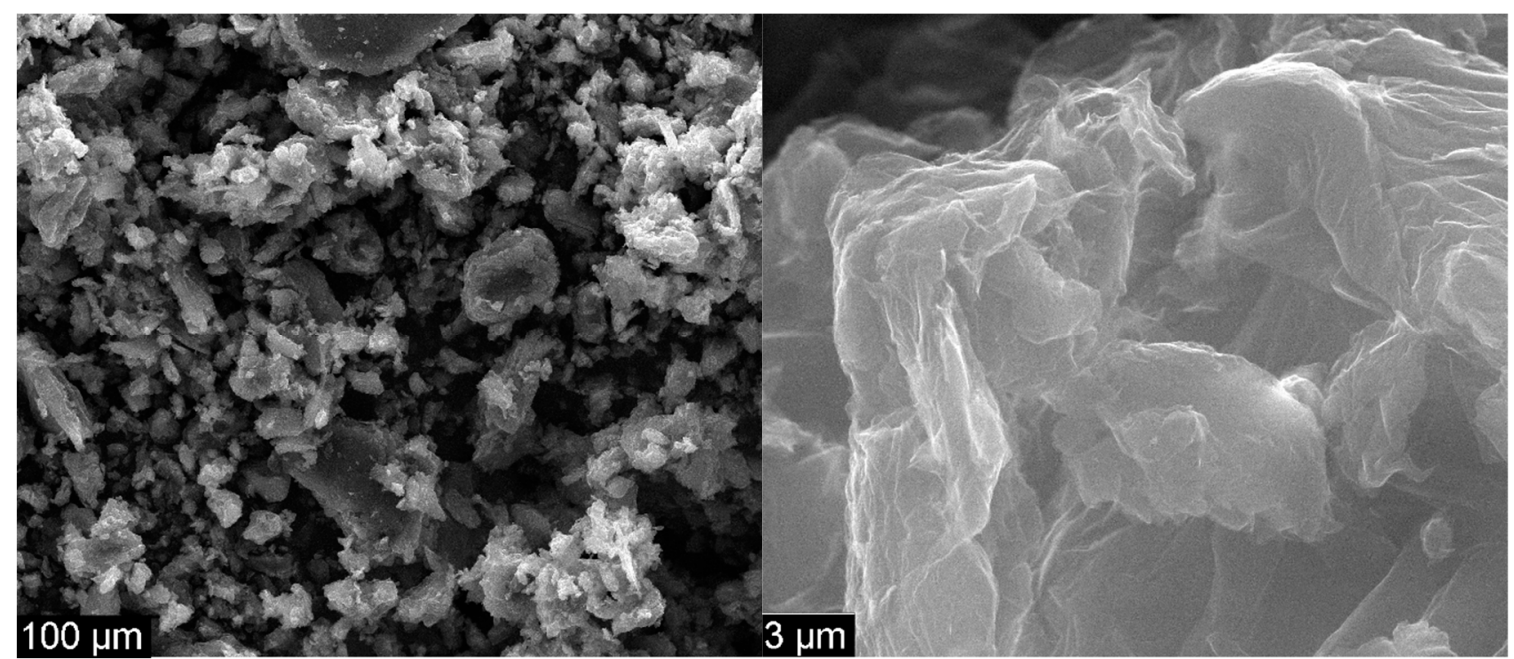

Figure 4. Scanning electron microscopy (SEM) images for GO at $1000 \times$ (left) and $50 \mathrm{k} \times$ magnification (right).

Figure 5 presents the surface morphology of CS.

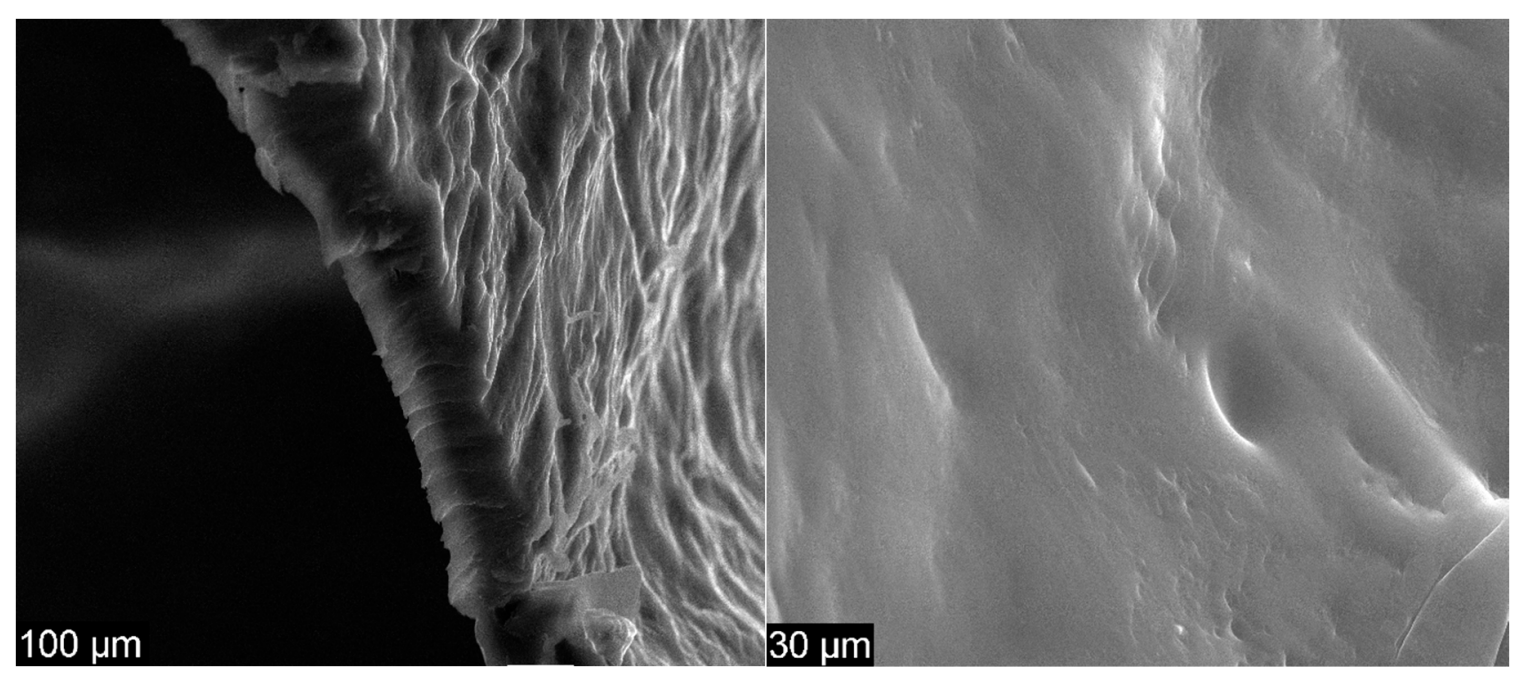

Figure 5. SEM images for CS at $1000 \times($ left) and $5000 \times$ magnification (right)

Figure 6 presents the surface characteristics of CS/EDTA films and also shows SEM images of CS/EDTA and CS/EDTA/GO with different GO content. 

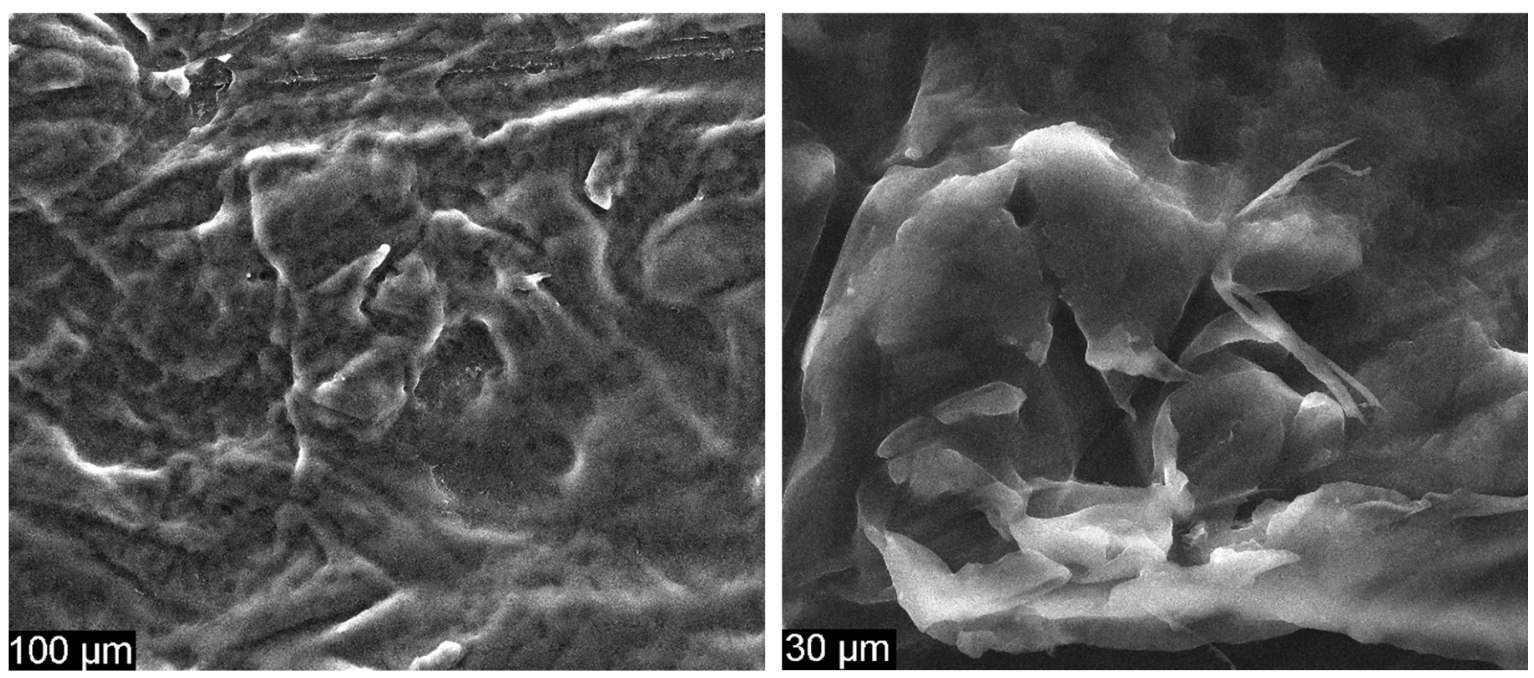

(a)

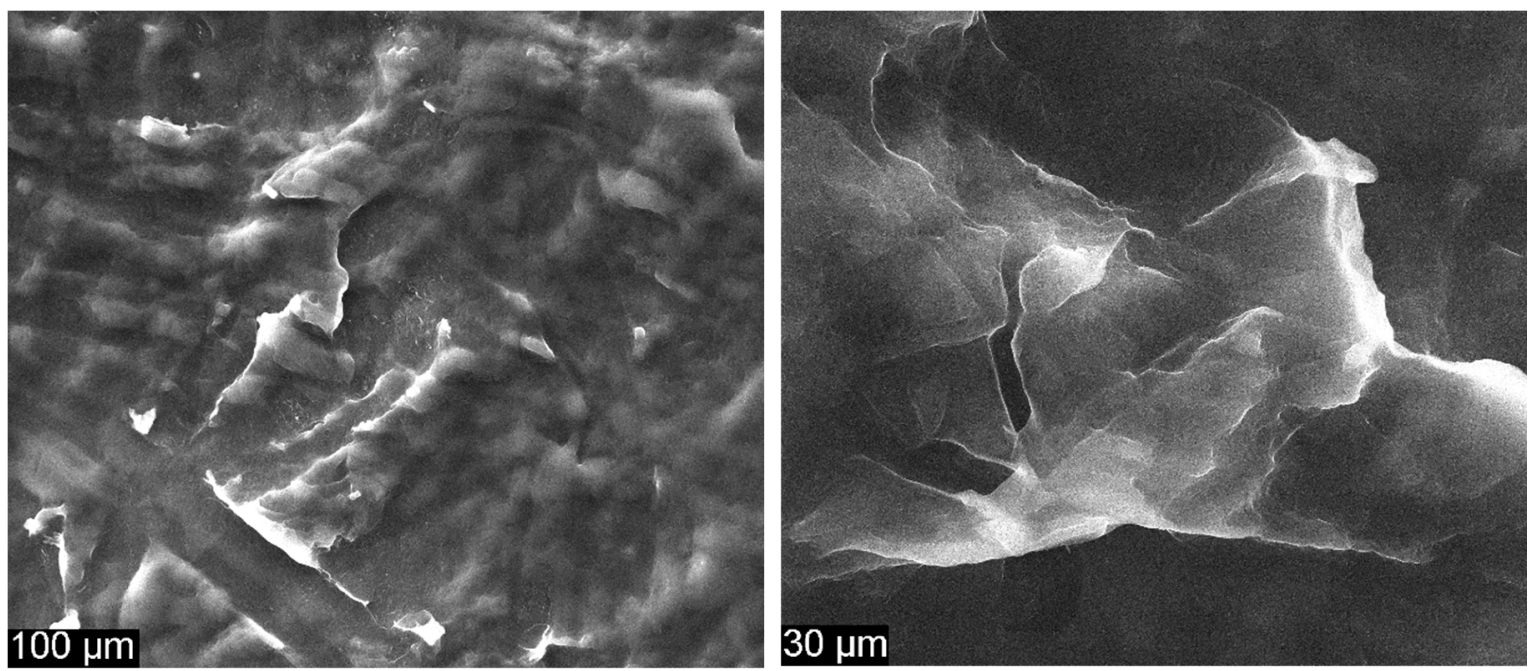

(b)
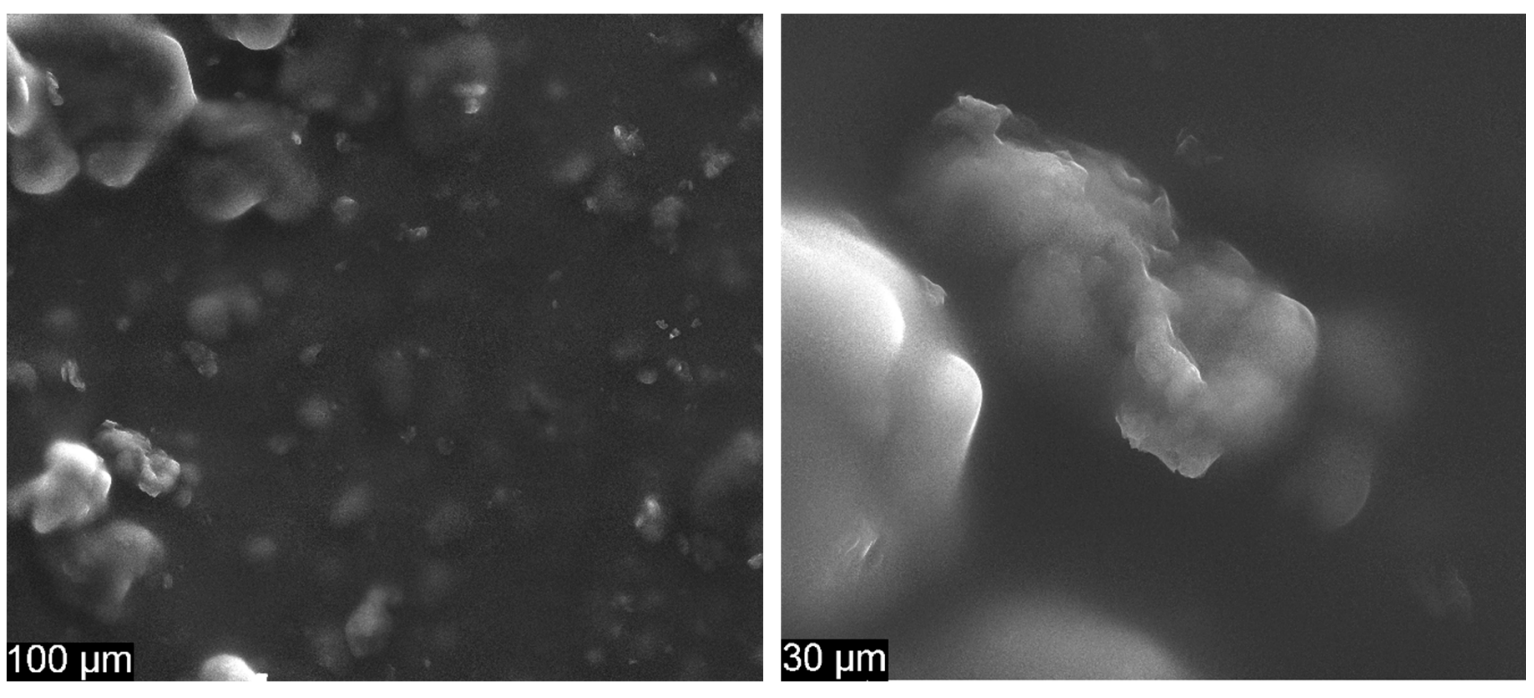

(c)

Figure 6. SEM images for (a) CS/EDTA, (b) CS/EDTA/GO $0.1 \%$ and (c) CS/EDTA/GO $0.3 \%$ at $1000 \times$ (left) and $5000 \times$ magnification (right). 
Following the calculations, a maximum adsorption capacity was observed for each film of $767 \mathrm{mg} \cdot \mathrm{g}^{-1}$ (CS/EDTA/GO, 0.1\%), $889 \mathrm{mg} \cdot \mathrm{g}^{-1}$ (CS/EDTA/GO 0.3\%), $970 \mathrm{mg} \cdot \mathrm{g}^{-1}$ (CS/EDTA), $853 \mathrm{mg} \cdot \mathrm{g}^{-1}$ (CS) and $1526 \mathrm{mg}^{-1}(\mathrm{GO})$.

Figure 7 shows the adsorption curves for GO and the prepared films.

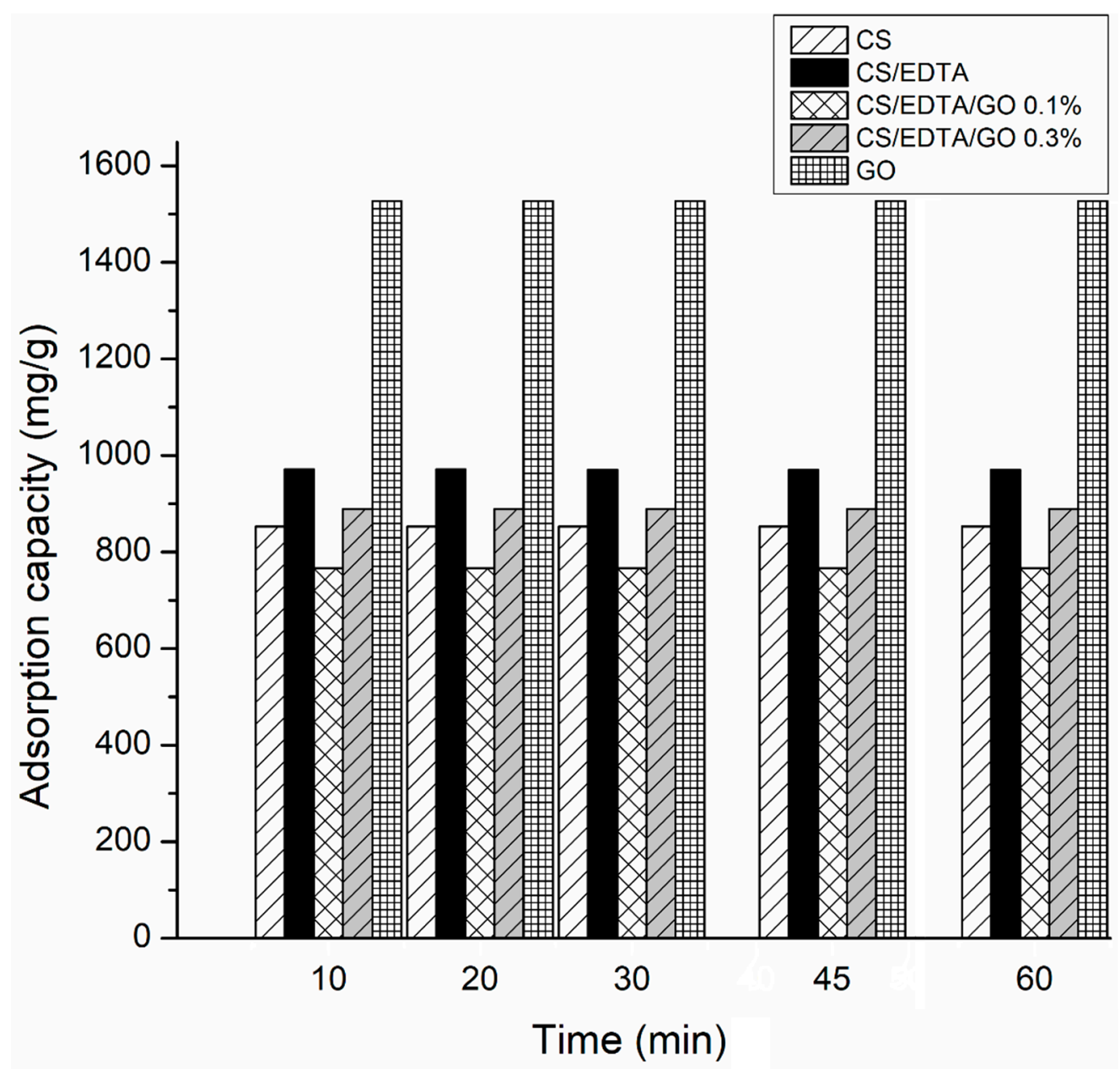

Figure 7. Sorption capacity of the membranes CS, CS/EDTA, CS/EDTA/GO $0.1 \%$, CS/EDTA/GO $0.3 \%$ and GO sheets. * Standard Deviation (SD) $=1-3 \%$.

\section{Discussion}

\subsection{Fourier Transform Infrared Spectroscopy}

Based on the IR spectrum of chitosan (Figure 2), it can be stated that the main characteristic peaks are clearly identified and are similar to those found in previous literature reports [30,31]. The wide absorption band between 3500 and $3000 \mathrm{~cm}^{-1}$ could be assigned to the $-\mathrm{OH}$ and $-\mathrm{NH}_{2}$ stretching vibrations of amino groups. The band between 2800 and $3000 \mathrm{~cm}^{-1}$ is attributed to the asymmetric stretching mode of $-\mathrm{CH}$ - groups of CS. The bands centered between 1450 and $1700 \mathrm{~cm}^{-1}$ are assigned to $\mathrm{C}=\mathrm{O}$ stretching vibration (amide $\mathrm{I}$ ) and $\mathrm{N}-\mathrm{H}$ bending vibration (amide II). The absorption peak at $1402 \mathrm{~cm}^{-1}$ corresponds to C-N stretching vibration (amide III) in CS. The band recorded at $1019 \mathrm{~cm}^{-1}$ is attributed to $\mathrm{C}-\mathrm{O}$ stretching vibrations [32,33]. The absorption bands were at 3430 and $1630 \mathrm{~cm}^{-1}$.

When compared with the original spectrum of CS, the FTIR spectrum of CS/EDTA (Figure 2) reveals several new absorption bands (1562 and $1511 \mathrm{~cm}^{-1}$, corresponding to the amide I and amide II groups). The absorption band around $3250 \mathrm{~cm}^{-1}$ corresponds to the stretching mode of $-\mathrm{OH}$ groups. The absorption band of the amide II group at $1541 \mathrm{~cm}^{-1}$ in CS shifts to $1544 \mathrm{~cm}^{-1}$ in the spectrum of the CS-EDTA film. Ionic bonds are formed when protonated amino groups of chitosan interact with 
carboxyl groups of EDTA, forming CS/EDTA suprastructures. By subtracting the spectrum of pure CS from the spectrum of the CS/EDTA nanocomposite, a visible widening of the peak around $1019 \mathrm{~cm}^{-1}$ can be seen, highlighting the interaction of CS with EDTA. The absorption band between 1500 and $1600 \mathrm{~cm}^{-1}$ corresponds to groups belonging to EDTA, and the band between 1100 and $1200 \mathrm{~cm}^{-1}$ is assigned to characteristic CS groups [34,35].

The FTIR spectra of GO (Figure 3) reveal specific bands of GO, similar to previous literature reports $[33,36,37]$. The peak from $1720 \mathrm{~cm}^{-1}$ is attributed to $\mathrm{C}=\mathrm{O}$ stretching vibration present in the $\mathrm{C}=\mathrm{O}$ and $\mathrm{COOH}$ of $\mathrm{GO}$. The absorption band at $1579 \mathrm{~cm}^{-1}$ corresponds to $\mathrm{C}=\mathrm{C}$ stretching vibration, and the bands at 1160 and $1030 \mathrm{~cm}^{-1}$ are attributed to $\mathrm{COC}$ and -COH stretching vibration groups. The broad peak at $3109 \mathrm{~cm}^{-1}$ is attributed to the associated -OH group from GO [33,36,37].

After the addition of GO, CS/EDTA/GO does not show important changes in FTIR peaks. However, a deformation in the vibration peak of amide I can be observed in conjunction with a shift in the band from 1545 to $1538 \mathrm{~cm}^{-1}$ due to the reaction of amino groups with epoxy groups, as stated by Cao et al. [38]. By subtracting the spectra of the two CS/EDTA/GO nanocomposites, an enhancement in the relative intensity of the peak from $1538 \mathrm{~cm}^{-1}$ can be observed due to the enhancement of GO concentration and the formation of hydrogen bonds between CS and GO, which demonstrates the interaction of GO with CS [39].

\subsection{Scanning Electron Microscopy}

The morphological structures of GO and chitosan-based membranes were determined by SEM at different magnifications, from $100 \times$ to $50 \mathrm{k} \times$.

Figure 4 presents the structure of GO at $1000 \times$ magnification as very thin agglomerated nanosheets. The waved and folded shape of GO is presented at $50 \mathrm{k} \times$ magnification, the results being similar to those found in previous studies $[28,29,40,41]$. The specific sheets of GO are not planar because GO has a high degree of functionalization. The width of GO was measured, and the results showed less than $20 \mu \mathrm{m}$ per individual sheet; this finding is similar to the literature [42]. In Figure 5, the surface of CS shows a generally smooth and uniform morphology without perforations and with few banded structures, which are attributable to the tendency of chitosan to self-aggregate in solution. The clear surface indicates no presence of GO [32,33]. Furthermore, according to the SEM images realized in the transversal section, the thickness of the CS membrane, as well as the other membranes, was in the tens of microns.

In Figure 6a, the illustrated CS/EDTA surface implies the unification of CS and EDTA in the composite material. Compared to pure CS, an increment in the density of the blended film can be seen, indicating a strong interaction between CS and EDTA [43].

A good dispersion of GO is also highlighted in CS/EDTA films (Figure 6b) without any aggregation, illustrating that CS/EDTA films blended with GO are compatible [44]. The inner structure of CS/EDTA/GO is much denser than the inner structure of CS, which leads to an increment in the mechanical strength of membranes [31,33]. Irregular wrapped zones assigned to the presence of GO platelets that can form during solvent evaporation (Figure $6 b, c)$ [45] can be seen. Thus, amino groups in CS and EDTA groups can form chemical bonds with a GO surface [43].

\subsection{Sorption Capacity of the Membranes}

The functionalization of CS with EDTA and loading with GO sheets can lead to an increase in the adsorption capacity against heavy metals. The oxygen functional sites from GO and EDTA can make CS/EDTA/GO an ideal adsorbent material for the elimination of toxic inorganic pollutants such as $\mathrm{Pb}^{2+}$, $\mathrm{Cu}^{2+}, \mathrm{Ni}^{2+}, \mathrm{Cd}^{2+}$ and so forth. [8]. Based on the literature data, lead can form strong complexes with oxygen functional groups such as $-\mathrm{COOH}$ and $-\mathrm{OH}$. The strong adsorption of $\mathrm{Pb}^{2+}$ can be attributed to the interactions between the cations of the metal ions and the oxygen groups of $\mathrm{GO}$, especially $-\mathrm{COOH}$ and $-\mathrm{OH}[46]$. 
Due to the strong and fast adsorption processes, these materials can be exploited in the elimination of $\mathrm{Pb}^{2+}$ ions from water solutions [8]. This study demonstrated that the adsorption capacity achieved an equilibrium state at $20 \mathrm{~min}$ (Figure 7), the films having a maximum adsorption capacity of $>99 \%$ when a standard solution of $\mathrm{Pb}^{2+}$ was used $(15 \mathrm{~mL}, 100 \mathrm{ppm})$ for each $20 \mathrm{mg}$ of adsorbent. After $20 \mathrm{~min}$, a slight deterioration of the membranes was observed, and $\mathrm{Pb}^{2+}$ ions were marginally released in the solution. The obtained membranes revealed maximum adsorption capacities of $767 \mathrm{mg} \cdot \mathrm{g}^{-1}$

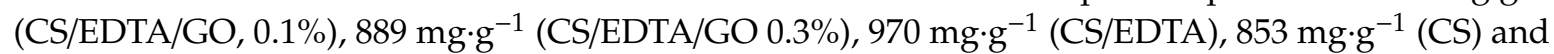
$1526 \mathrm{mg} \cdot \mathrm{g}^{-1}$ (GO). For each membrane, three samples were analyzed, and the standard deviation value was between $1 \%$ and $3 \%$. The results showed a higher adsorption capacity of CS/EDTA/GO $0.3 \%$ compared to that of CS/EDTA/GO 0.1\%, which can be attributed to the increase in GO concentration. The lower performances observed in CS/EDTA/GO compared to CS/EDTA membranes can be attributed to the the chemical interaction between negative groups of CS, EDTA and GO such as $-\mathrm{NH}_{2},-\mathrm{OH}$ and $-\mathrm{COOH}$ groups with metal ions that inhibit the adsorption of $\mathrm{Pb}^{2+}$ ions on the membranes. Nevertheless, the addition of GO to CS/EDTA film is of great interest due to the abundant oxygen functional sites, leading to an increase in adsorption capacity against heavy metals [47].

\section{Conclusions}

GO-based CS membranes functionalized with EDTA were successfully prepared using an aqueous solution of acetic acid as solvent. Adding EDTA to CS solution can help increase the adsorption process for $\mathrm{Pb}^{2+}$ ions. Hydroxyl and carboxyl groups from both GO and EDTA can make CS/EDTA/GO ideal adsorbents for the elimination of inorganic metal ions, such as $\mathrm{Pb}^{2+}, \mathrm{Cu}^{2+}, \mathrm{Ni}^{2+}, \mathrm{Cd}^{2+}$ and so forth, from wastewater. GO powder disperses very well in CS solution, creating strong hydrogen bonds between the $-\mathrm{OH}$ groups of $\mathrm{CS}$ and $-\mathrm{OH}$ groups of GO. The obtained films showed high affinity for $\mathrm{Pb}^{2+}$ ions in aqueous solutions with maximum adsorption values of $767 \mathrm{mg} \cdot \mathrm{g}^{-1}$ (CS/EDTA/GO, $0.1 \%), 889 \mathrm{mg} \cdot \mathrm{g}^{-1}$ (CS/EDTA/GO 0.3\%), $970 \mathrm{mg} \cdot \mathrm{g}^{-1}$ (CS/EDTA), $853 \mathrm{mg} \cdot \mathrm{g}^{-1}$ (CS) and $1526 \mathrm{mg} \cdot \mathrm{g}^{-1}$ (GO). It is important to mention that CS/EDTA/GO membranes had lower performances as compared to $\mathrm{CS} /$ EDTA, most probably because some of the $-\mathrm{NH}_{2},-\mathrm{OH}$ and $-\mathrm{COOH}$ groups of the CS, EDTA and GO formed strong $\mathrm{H}$ bonds unavailable for binding $\mathrm{Pb}^{2+}$. Because $\mathrm{GO}$ is more expensive than other natural and carbon materials, it is important to fabricate a low-cost adsorbent material that has great adsorption capacity. Thus, the functionalization of CS with EDTA and GO can make CS/EDTA/GO an excellent adsorbent material for heavy metal removal. This work demonstrates that CS-based membranes have great adsorption properties in the removal of toxic metal ions from wastewater. Following these results, other promising applications of these membranes can be proposed, such as biomaterials or bioactive packaging materials for the food industry.

Author Contributions: This article was written with contributions from all authors, methodology and writing-original draft preparation A.-M.C., conceptualization and visualization A.F., writing-review and efiting D.F., formal analysis R.T., formal analysis G.D., project administrator and visualization E.A., supervision and writing-review and editing S.C.T. All authors have given approval to the final version of the manuscript.

Funding: Academy of Romanian Scientists sponsored this research.

Acknowledgments: Alexa-Maria Croitoru thanks the Academy of Romanian Scientists for financial support.

Conflicts of Interest: The authors declare no conflicts of interest.

\section{References}

1. Najafabadi, H.H.; Irani, M.; Rad, L.R.; Haratameh, A.H.; Haririan, I. Removal of $\mathrm{Cu}^{2+}, \mathrm{Pb}^{2+}$ and $\mathrm{Cr}^{6+}$ from aqueous solutions using a chitosan/graphene oxide composite nanofibrous adsorbent. RSC Adv. 2015, 5, 16532-16539. [CrossRef]

2. Lai, K.C.; Lee, L.Y.; Hiew, B.Y.Z.; Thangalazhy-Gopakumar, S.; Gan, S.Y. Environmental application of three-dimensional graphene materials as adsorbents for dyes and heavy metals: Review on ice-templating method and adsorption mechanisms. J. Environ. Sci. China 2019, 79, 174-199. [CrossRef] [PubMed] 
3. Wang, Y.; Liu, X.; Wang, H.F.; Xia, G.M.; Huang, W.; Song, R. Microporous spongy chitosan monoliths doped with graphene oxide as highly effective adsorbent for methyl orange and copper nitrate $\left(\mathrm{Cu}\left(\mathrm{NO}_{3}\right)(2)\right)$ ions. J. Colloid Interface Sci. 2014, 416, 243-251. [CrossRef] [PubMed]

4. Zhang, N.N.; Qiu, H.X.; Si, Y.M.; Wang, W.; Gao, J.P. Fabrication of highly porous biodegradable monoliths strengthened by graphene oxide and their adsorption of metal ions. Carbon 2011, 49, 827-837. [CrossRef]

5. Ihsanullah; Abbas, A.; Al-Amer, A.M.; Laoui, T.; Al-Marri, M.J.; Nasser, M.S.; Khraisheh, M.; Atieh, M.A. Heavy metal removal from aqueous solution by advanced carbon nanotubes: Critical review of adsorption applications. Sep. Purif. Technol. 2016, 157, 141-161. [CrossRef]

6. Qu, X.L.; Alvarez, P.J.J.; Li, Q.L. Applications of nanotechnology in water and wastewater treatment. Water Res. 2013, 47, 3931-3946. [CrossRef]

7. Jiang, Z.; Yu, F.; Ma, J. Design of Graphene-based Adsorbents and Its Removal of Antibiotics in Aqueous Solution. Acta Phys. Chim. Sin. 2019, 35, 709-724.

8. Madadrang, C.J.; Kim, H.Y.; Gao, G.H.; Wang, N.; Zhu, J.; Feng, H.; Gorring, M.; Kasner, M.L.; Hou, S.F. Adsorption Behavior of EDTA-Graphene Oxide for Pb (II) Removal. ACS Appl. Mater. Interfaces 2012, 4, 1186-1193. [CrossRef]

9. Zhou, C.Y.; Xu, P.; Lai, C.; Zhang, C.; Zeng, G.M.; Huang, D.L.; Cheng, M.; Hu, L.; Xiong, W.P.; Wen, X.F.; et al. Rational design of graphic carbon nitride copolymers by molecular doping for visible-light-driven degradation of aqueous sulfamethazine and hydrogen evolution. Chem. Eng. J. 2019, 359, 186-196. [CrossRef]

10. Wang, X.Y.; Wang, A.Q.; Ma, J. Visible-light-driven photocatalytic removal of antibiotics by newly designed $\mathrm{C}_{3} \mathrm{~N}_{4} @ \mathrm{MnFe}_{2} \mathrm{O}_{4}$-graphene nanocomposites. J. Hazard. Mater. 2017, 336, 81-92. [CrossRef]

11. Yahya, N.; Aziz, F.; Jamaludin, N.A.; Mutalib, M.A.; Ismail, A.F.; Salleh, W.N.W.; Jaafar, J.; Yusof, N.; Ludin, N.A. A review of integrated photocatalyst adsorbents for wastewater treatment. J. Environ. Chem. Eng. 2018, 6, 7411-7425. [CrossRef]

12. Politano, G.G.; Cazzanelli, E.; Versace, C.; Vena, C.; De Santo, M.P.; Castriota, M.; Ciuchi, F.; Bartolino, R. Graphene oxide on magnetron sputtered silver thin films for SERS and metamaterial applications. Appl. Surf. Sci. 2018, 427, 927-933. [CrossRef]

13. Yang, Q.-D.; Cheng, Y.; Li, H.-W.; Guan, Z.; Yu, B.; Li, J.; Tsang, S.-W. Graphene Oxide as Efficient Hole-Transporting Material for High-Performance Perovskite Solar Cells with Enhanced Stability. J. Mater. Chem. A 2017, 5, 9852-9858. [CrossRef]

14. Sun, Y.; Tang, J.; Zhang, K.; Yuan, J.; Li, J.; Zhu, D.-M.; Ozawa, K.; Qin, L.-C. Comparison of reduction products from graphite oxide and graphene oxide for anode applications in lithium-ion batteries and sodium-ion batteries. Nanoscale 2017, 9, 2585-2595. [CrossRef]

15. Owens, F.J. Density Functional Modeling of Boron Doped Carbon Nano-Structures as Catalysts in Fuel Cells. Adv. Nanomater. Technol. Energy Sect. 2017, 1, 39-46.

16. Ficai, A.; Somnez, M.; Ficai, D.; Andronescu, E. Graphene based materials for environmental applications. Adv. Mater. Technol. Environ. Appl. 2017, 1,79-85.

17. Chen, L.; Li, Y.H.; Du, Q.J.; Wang, Z.H.; Xia, Y.Z.; Yedinak, E.; Lou, J.; Ci, L.J. High performance agar/graphene oxide composite aerogel for methylene blue removal. Carbohydr. Polym. 2017, 155, 345-353. [CrossRef]

18. Wang, H.; Chen, Y.N.; Wei, Y.M. A novel magnetic calcium silicate/graphene oxide composite material for selective adsorption of acridine orange from aqueous solutions. RSC Adv. 2016, 6, 34770-34781. [CrossRef]

19. Lotfi, Z.; Mousavi, H.Z.; Sajjadi, S.M. Covalently bonded double-charged ionic liquid on magnetic graphene oxide as a novel, efficient, magnetically separable and reusable sorbent for extraction of heavy metals from medicine capsules. RSC Adv. 2016, 6, 90360-90370. [CrossRef]

20. Chen, Y.Q.; Chen, L.B.; Bai, H.; Li, L. Graphene oxide-chitosan composite hydrogels as broad-spectrum adsorbents for water purification. J. Mater. Chem. A 2013, 1, 1992-2001. [CrossRef]

21. Crini, G.; Badot, P.M. Application of chitosan, a natural aminopolysaccharide, for dye removal from aqueous solutions by adsorption processes using batch studies: A review of recent literature. Prog. Polym. Sci. 2008, 33, 399-447. [CrossRef]

22. Park, C.M.; Kim, Y.M.; Kim, K.H.; Wang, D.J.; Su, C.M.; Yoon, Y. Potential utility of graphene-based nano spinel ferrites as adsorbent and photocatalyst for removing organic/inorganic contaminants from aqueous solutions: A mini review. Chemosphere 2019, 221, 392-402. [CrossRef] [PubMed]

23. Thomas, V.J.; Ramaswamy, S. Application of Graphene and Graphene Compounds for Environmental Remediation. Sci. Adv. Mater. 2016, 8, 477-500. [CrossRef] 
24. Gonavelli, G.; Chang, C.C.; Ling, Y.C. Facile Synthesis of Smart Magnetic Graphene for Safe Drinking Water: Heavy Metal Removal and Disinfection Control. ACS Sustain. Chem. Eng. 2013, 1, 462-472. [CrossRef]

25. Chen, H.; Gao, B.; Li, H. Removal of sulfamethoxazole and ciprofloxacin from aqueous solutions by graphene oxide. J. Hazard. Mater. 2015, 282, 201-207. [CrossRef]

26. Chowdhury, S.; Das Saha, P. Adsorption of malachite green from aqueous solution by NaOH-modified rice husk: Fixed-bed column studies. Environ. Prog. Sustain. Energy 2013, 32, 633-639. [CrossRef]

27. Harijan, D.K.L.; Chandra, V. Polyaniline functionalized graphene sheets for treatment of toxic hexavalent chromium. J. Environ. Chem. Eng. 2016, 4, 3006-3012. [CrossRef]

28. Zaaba, N.I.; Foo, K.L.; Hashim, U.; Tan, S.J.; Liu, W.W.; Voon, C.H. Synthesis of Graphene Oxide using Modified Hummers Method: Solvent Influence. Adv. Mater. Process. Technol. Conf. 2017, 184, 469-477. [CrossRef]

29. Croitoru, A.; Oprea, O.; Nicoara, A.; Trusca, R.; Radu, M.; Neacsu, I.; Ficai, D.; Ficai, A.; Andronescu, E. Multifunctional Platforms Based on Graphene Oxide and Natural Products. Med. Lith. 2019, 55, 230. [CrossRef]

30. Soltani, S.; Ebrahimian-Hosseinabadi, M.; Kharazi, A.Z. Chitosan/graphene and poly(D, L-lactic-co-glycolic acid)/graphene nano-composites for nerve tissue engineering. Tissue Eng. Regen. Med. 2016, 13, 684-690. [CrossRef]

31. Gea, S.; Sari, J.N.; Bulan, R.; Piliang, A.; Amaturrahim, S.A.; Hutapea, Y.A. Chitosan/graphene oxide biocomposite film from pencil rod. Int. Conf. Innov. Educ. Sci. Cult. 2018, 970. [CrossRef]

32. Ziani, K.; Oses, J.; Coma, V.; Mate, J.I. Effect of the presence of glycerol and Tween 20 on the chemical and physical properties of films based on chitosan with different degree of deacetylation. LWT Food Sci. Technol. 2008, 41, 2159-2165. [CrossRef]

33. Han, D.L.; Yan, L.F.; Chen, W.F.; Li, W. Preparation of chitosan/graphene oxide composite film with enhanced mechanical strength in the wet state. Carbohydr. Polym. 2011, 83, 653-658. [CrossRef]

34. Fujita, S.; Sakairi, N. Water soluble EDTA-linked chitosan as a zwitterionic flocculant for $\mathrm{pH}$ sensitive removal of $\mathrm{Cu}(\mathrm{II})$ ion. RSC Adv. 2016, 6, 10385-10392. [CrossRef]

35. Yue, L.; Wang, J.; Pan, K.; Zhang, X.M.; Wang, Z.P.; Xia, W.S. Preparation and Characterization of Core/Shell-type Ag/Chitosan Nanoparticles with Antibacterial Activity. Bull. Korean Chem. Soc. 2011, 32, 1277-1281.

36. Wang, K.; Ruan, J.; Song, H.; Zhang, J.; Wo, Y.; Guo, S.; Cui, D. Biocompatibility of Graphene Oxide. Nanoscale Res. Lett. 2011, 6, 8. [CrossRef] [PubMed]

37. Han, W.; Niu, W.Y.; Sun, B.; Shi, G.C.; Cui, X.Q. Biofabrication of polyphenols stabilized reduced graphene oxide and its anti-tuberculosis activity. J. Photochem. Photobiol. B 2016, 165, 305-309. [CrossRef]

38. Cao, L.; Zhang, F.; Wang, Q.G.; Wu, X.F. Fabrication of chitosan/graphene oxide polymer nanofiber and its biocompatibility for cartilage tissue engineering. Mater. Sci. Eng. C Mater. Biol. Appl. 2017, 79, 697-701. [CrossRef]

39. Chen, L.; Jiang, H.; Li, Y.M.; Zimba, B.L.; Yu, X.Z.; Chen, C.; Xiong, G.X.; Wu, Q.Z. Influences on mechanical properties of chitosan nanofibrous membranes induced by incorporating graphene oxide nanosheets. Mater. Res. Express 2019, 6. [CrossRef]

40. Gurunathan, S.; Han, J.W.; Eppakayala, V.; Kim, J.H. Green synthesis of graphene and its cytotoxic effects in human breast cancer cells. Int. J. Nanomed. 2013, 8, 1015-1027. [CrossRef]

41. Li, J.D.; Wei, L.F.; Yu, C.L.; Fang, W.; Xie, Y.; Zhou, W.Q.; Zhu, L.H. Preparation and characterization of graphene oxide/ $\mathrm{Ag}_{2} \mathrm{CO}_{3}$ photocatalyst and its visible light photocatalytic activity. Appl. Surf. Sci. 2015, 358, 168-174. [CrossRef]

42. Alam, S.N.; Sharma, N.; Kumar, L. Synthesis of Graphene Oxide (GO) by Modified Hummers Method and Its Thermal Reduction to Obtain Reduced Graphene Oxide (rGO)*. Graphene 2017, 6, 1-18. [CrossRef]

43. Shahzad, A.; Miran, W.; Rasool, K.; Nawaz, M.; Jang, J.; Lim, S.-R.; Lee, D.S. Heavy metals removal by EDTA-functionalized chitosan graphene oxide nanocomposites. RSC Adv. 2017, 7, 9764-9771. [CrossRef]

44. Yang, X.M.; Tu, Y.F.; Li, L.A.; Shang, S.M.; Tao, X.M. Well-Dispersed Chitosan/Graphene Oxide Nanocomposites. ACS Appl. Mater. Interfaces 2010, 2, 1707-1713. [CrossRef] [PubMed]

45. Frindy, S.; Primo, A.; Ennajih, H.; Qaiss, A.E.; Bouhfid, R.; Lahcini, M.; Essassi, E.; Garcia, H.; El Kadib, A. Chitosan-graphene oxide films and $\mathrm{CO}_{2}$-dried porous aerogel microspheres: Interfacial interplay and stability. Carbohydr. Polym. 2017, 167, 297-305. [CrossRef] [PubMed] 
46. Zhao, G.X.; Li, J.X.; Ren, X.M.; Chen, C.L.; Wang, X.K. Few-Layered Graphene Oxide Nanosheets As Superior Sorbents for Heavy Metal Ion Pollution Management. Environ. Sci. Technol. 2011, 45, 10454-10462. [CrossRef]

47. Wang, J.; Huang, T.F.; Zhang, L.; Yu, Q.J.; Hou, L.A. Dopamine crosslinked graphene oxide membrane for simultaneous removal of organic pollutants and trace heavy metals from aqueous solution. Environ. Technol. 2018, 39, 3055-3065. [CrossRef]

(C) 2020 by the authors. Licensee MDPI, Basel, Switzerland. This article is an open access article distributed under the terms and conditions of the Creative Commons Attribution (CC BY) license (http://creativecommons.org/licenses/by/4.0/). 